\title{
Comparison of the 16S Ribosomal DNA Sequences from the Intracellular Agents of Proliferative Enteritis in a Hamster, Deer, and Ostrich with the Sequence of a Porcine Isolate of Lawsonia intracellularis
}

\author{
DALE M. COOPER, ${ }^{1 *}$ DEBRA L. SWANSON,${ }^{1}$ SUSAN M. BARNS,${ }^{2}$ AND CONNIE J. GEBHART ${ }^{1}$ \\ Division of Comparative Medicine, Research Animal Resources, Medical School, University of Minnesota, Minneapolis, \\ Minnesota 55455, ${ }^{1}$ and Environmental Molecular Biology, Life Sciences Division, Los Alamos National Laboratory, \\ Los Alamos, New Mexico $87545^{2}$
}

\begin{abstract}
Proliferative enteritis is an enteric disease that affects a variety of animals. The causative agent in swine has been determined to be an obligate intracellular bacterium, Lawsonia intracellularis, related to the sulfatereducing bacterium Desulfovibrio desulfuricans. The intracellular agents found in the lesions of different animal species are antigenically similar. In addition, strains from the pig, ferret, and hamster have been shown to be genetically similar. In this study we performed a partial $16 \mathrm{~S}$ ribosomal DNA sequence analysis on the intracellular agent of proliferative enteritis from a hamster, a deer, and an ostrich and compared these sequences to that of the porcine $L$. intracellularis isolate. Results of this study indicate that the intracellular agents from these species with proliferative enteritis have high sequence similarity, indicating that they are all in the genus Lawsonia and that they may also be the same species, L. intracellularis.
\end{abstract}

Proliferative enteritis (PE) is an enteric disease that occurs primarily in weanling animals but is also seen in older animals. It has been reported in a variety of species, including the pig, hamster, ferret, fox, rat, rabbit $(27)$, horse $(5,34)$, deer (4), ostrich (36), and emu (17). The disease has been most thoroughly studied in the pig and the hamster (27). It may be chronic. causing weight loss and poor growth, or more acute, occasionally resulting in death. Antibiotics may be used to treat $\mathrm{PE}$; however, many cases resolve spontaneously. The disease is widespread in swine. Poor weight gain and deaths during epizootics result in production loss and represent a significant cost to the swine industry $(14,27)$. The significance of PE in other species is not known. Because of the wide host range of the disease, it is likely that there are numerous reservoirs, and the disease may represent an equally serious threat to these species.

PE causes hyperplasia of the intestinal mucosa, specifically the crypt epithelial cells. Large numbers of small, curved intracellular bacteria are present within the proliferating cells (27). The disease may be diagnosed by observation of these lesions at necropsy, by detecting the intracellular organism in histologic sections with silver strain (27), or by various immunologic $(15,20)$ and molecular $(8,9,12,13,19,22)$ methods. Serologic diagnosis of PE has not proven to be useful $(10,16)$. The organism has been isolated in cell cultures from hamsters and pigs with PE but has not been grown on cell-free medium $(15,31)$. Transmission studies have shown that this bacterium is the causative agent of $\mathrm{PE}$ in pigs $(15,23)$ and probably hamsters (31). Sequence analysis of the $16 \mathrm{~S}$ ribosomal DNA (rDNA) of this bacterium shows that it is most closely related to the sulfate-reducing bacterium Desulfovibrio desulfuricans. The organism was given the vernacular name of ileal symbiont intracellularis (7), which has recently been formalized to Lawsonia intracellularis (21).

${ }^{*}$ Corresponding author. Mailing address: Division of Comparative Medicine, Research Animal Resources, Medical School, Box 351 UMHC, 420 Delaware St. SE, Minneapolis, MN 55455. Phone: (612) 624-9100. Fax: (612) 625-7632.
The intracellular agents of $\mathrm{PE}$ are morphologically identical in all species that the disease affects $(4,5,17,27,34,36)$. The ability of monoclonal antibodies developed from a pig isolate of the organism to detect the organism in tissues from other species demonstrates that the intracellular organisms seen in lesions from different species are antigenically similar $(4,6,14$, $24,34,36)$. Sequence analysis of the $16 \mathrm{~S}$ rDNA from this organism from the pig $(7,21)$, the hamster $(6,26)$, and the ferret (6) suggests that the intracellular agents of PE in these species are also genetically similar.

In this study we performed a complete $16 \mathrm{~S}$ rDNA sequence analysis of the intracellular agent of $\mathrm{PE}$ in the hamster and a partial 16S rDNA sequence analysis on the intracellular agent of PE extracted from formalin-fixed, paraffin-embedded tissues from a deer and an ostrich with PE. The sequence obtained demonstrated high similarity between the $16 \mathrm{~S}$ rDNA from the intracellular agent of PE from these species and that of the pig isolate of $L$. intracellularis. These results suggest that the intracellular agents of PE in the hamster, deer, and ostrich are all isolates of $L$. intracellularis.

\section{MATERIALS AND METHODS}

Samples. The hamster intracellular agent of PE (strain auratus) was grown in INT 407 human embryonic intestinal epithelial cells, and the DNA was extracted for PCR and sequence analysis. The organism was fed to newly weaned hamsters (Mesocricetus auratus) according to protocols previously described (31). The animals were necropsied at 21 days, and the ilea were harvested. Ilea from one of these experimentally infected hamsters and from a deer (Odocoileus virginianus 93-3669) and an ostrich (Struthio camelus D94-06196) with spontaneous PE were examined. PE was diagnosed by histopathologic examination of formalinfixed, paraffin-embedded tissues stained with Warthin-Starry silver stain and by multiplex PCR (2). (The hamster organism was kindly provided by Harold Stills, College of Veterinary Medicine, Ohio State University, Columbus. Deer tissues were kindly provided by Richard Drolét, Université de Montréal, Québec, Canada. Ostrich tissues were kindly provided by Leslie Woods, Veterinary Diagnostic Laboratory, University of California, Davis.) Tissues frozen at $-70^{\circ} \mathrm{C}$ or formalin-fixed, paraffin-embedded samples of the ilea from these animals were selected for DNA extraction, amplification, cloning, and sequencing.

Sample digestion. Formalin-fixed, paraffin-embedded samples were digested by methods similar to the procedures of Isola et al. (11). Briefly, 10 to 20 5 - $\mu \mathrm{m}$-thick slices were cut from each block, deparaffinized once in $1 \mathrm{ml}$ of xylene, and rinsed twice in $100 \%$ ethanol. Samples were dried at room temperature and resuspended in $1 \mathrm{ml}$ of DNA extraction buffer $(0.3 \mathrm{mg}$ of proteinase $\mathrm{K} / \mathrm{ml}, 100$ 
$\mathrm{mM} \mathrm{NaCl}, 10 \mathrm{mM}$ Tris- $\mathrm{HCl}$ [pH 8], $25 \mathrm{mM}$ EDTA [pH 8], 0.5\% sodium dodecy] sulfate). Samples were incubated at $56^{\circ} \mathrm{C}$ for 3 days with $0.2 \mathrm{mg}$ of proteinase $\mathrm{K}$ added after 24 and $48 \mathrm{~h}$. After $72 \mathrm{~h}$, the samples were cooled to $4^{\circ} \mathrm{C}$ prior to DNA extraction

DNA extraction. DNA was extracted from cultured cells with a phenol-chloroform cxtraction (28). DNA was extracted from tissue samples with diatomaceous earth and guanidine thiocyanate (GuSCN) as described by Boom et al. (1) Briefly, $0.5 \mathrm{ml}$ of a sample was mixed with $0.9 \mathrm{ml}$ of lysis buffer $(6 \mathrm{M} \mathrm{GuSCN}, 0.1$ $\mathrm{M}$ Tris- $\mathrm{HCl}[\mathrm{pH} 6.4], 0.65 \%$ Triton X-100) and $40 \mu$ l of diatomaceous-earth suspension $(200 \mathrm{mg} / \mathrm{ml}$ of $0.17 \mathrm{M} \mathrm{HCl})$. The sample was vortexed, incubated at $20^{\circ} \mathrm{C}$ for $10 \mathrm{~min}$, vortexed again, and pelleted at $14,000 \times \mathrm{g}$ for $20 \mathrm{~s}$. The pellet was rinsed twice in $200 \mu \mathrm{l}$ of GuSCN rinse $(6 \mathrm{M} \mathrm{GuSCN}, 0.1 \mathrm{M}$ Tris- $\mathrm{HCl}[\mathrm{pH}$ 6.41) and twice in $200 \mu \mathrm{l}$ of $70 \%$ ethanol, with vortexing and pelleting of the sample with each rinse. The pellet was dried at $20{ }^{\circ} \mathrm{C}$ overnight and resuspended in $100 \mu \mathrm{l}$ of PCR buffer $\left(10 \mathrm{mM}\right.$ Tris- $\mathrm{HCl}[\mathrm{pH} 8.3], 50 \mathrm{mM} \mathrm{KCl}, 1.5 \mathrm{mM} \mathrm{MgCl} \mathrm{Mg}_{2}$ ). The sample was incubated at $56^{\circ} \mathrm{C}$ for $10 \mathrm{~min}$, vortexed, and pelleted at $14,000 \times$ $g$ for 2 min, and the supernatant was saved for PCR.

PCR primers. Primers used for PCR amplification of the 16S rDNA of the hamster organism were primer pairs fD1-rP1, described by Weisburg et al. (33) and previously used to sequence the $16 \mathrm{~S}$ rDNA sequence of $L$. intracellularis (7, 21). Each pair is capable of initiating amplification of nearly full-length $16 \mathrm{~S}$ rDNA $(1.6 \mathrm{~kb})$ from a taxonomically wide range of bacteria. Extension primers were developed from internal sequences as needed. Primers used for the partial $16 \mathrm{~S}$ rDNA sequence analysis of the intracellular organism from the deer and ostrich were derived from the $16 \mathrm{~S}$ rDNA sequence of the $L$. intracellularis type strain, NCTC 12656 (National Collection of Type Cultures, Collindale, London, England), purified from the ileal mucosa of a pig with PE (7). The sequences of these primers are as follows: $878 \mathrm{~F}$ (sense), 5'-TAACGCGTTAAGCA(C/T)C-3 (bp 868 to 883), and 1100R (antisense), 5'-AGGGTTGCGCTCGTTG-3' (bp 1107 to 1122). The expected product from these primers is 255 bp long.

PCR. PCR was performed in a $50-\mu l$ volume containing PCR buffer $(10 \mathrm{mM}$ Tris- $\mathrm{HCl}[\mathrm{pH} 8.3], 50 \mathrm{mM} \mathrm{KCl}, 2.0 \mathrm{mM} \mathrm{MgCl}$ ), $177 \mathrm{ng}$ of the appropriate primer, $0.2 \mathrm{mM}$ (cach) dATP, dGTP, dCTP, and dTTP, and $1 \mu l$ of extracted sample DNA $(\sim 1 \mathrm{ng})$ or $1 \mu \mathrm{l}$ of sterile distilled water as a negative control. The mixture was heated to $95^{\circ} \mathrm{C}$ for $5 \mathrm{~min}$ and cooled to $4^{\circ} \mathrm{C}$, and $1 \mathrm{U}$ of $\mathrm{Taq}$ polymerase (Boehringer Mannheim, Indianapolis, Ind.) was added. The sample was subjected to 35 cycles of PCR (DNA thermal cycler 480; Perkin-Elmer, Foster City, Calif.) with an amplification sequence of $93^{\circ} \mathrm{C}$ for $30 \mathrm{~s}, 45^{\circ} \mathrm{C}$ for 1 min, and $72^{\circ} \mathrm{C}$ for $1 \mathrm{~min}$

Agarose gel electrophoresis. PCR products from mucosal samples and plasmids purified from clones, described in the next section, were analyzed by agarose gel electrophoresis. Briefly, $10 \mu \mathrm{l}$ of the PCR product or of a 1:10 dilution of plasmid was combined with $5 \mu \mathrm{l}$ of gel loading solution (40\% sucrose, $0.1 \mathrm{M}$ EDTA [pH 8.0], $0.5 \%$ sodium dodecyl sulfate, and $0.05 \%$ bromphenol blue; Sigma, St. Louis, Mo.) and subjected to agarose gel electrophoresis on $2 \%$ agarose gel in TAE buffer $(0.04 \mathrm{M}$ Tris-acetate, $0.001 \mathrm{M}$ EDTA with $0.8 \mu \mathrm{g}$ of ethidium bromide/ml) for $1.5 \mathrm{~h}$ at $60 \mathrm{~V}$ and photographed under UV illumination.

Cloning. The PCR products were cloned into a 3.9-kbp plasmid vector (TA cloning kit; Invitrogen, San Dicgo, Calif.) according to the manufacturer's directions. Briefly, $7 \mu \mathrm{l}(\sim 7 \mathrm{ng})$ of PCR product was added to $50 \mathrm{ng}$ of pCR vector and $4 \mathrm{U}$ of T4 DNA ligase in ligation buffer $(60 \mathrm{mM}$ Tris- $\mathrm{HCl}[\mathrm{pH} 7.5], 60 \mathrm{mM}$ $\mathrm{MgCl}_{2}, 50 \mathrm{mM} \mathrm{NaCl}, 1 \mathrm{mg}$ of bovine serum albumin $/ \mathrm{ml}, 70 \mathrm{mM} \beta$-mercaptoethanol, $1 \mathrm{mM}$ ATP, $20 \mathrm{mM}$ dithiothreitol, and $10 \mathrm{mM}$ spermidine) and incubated at $12^{\circ} \mathrm{C}$ for $16 \mathrm{~h}$. One microliter of the ligation reaction mixture was added to $50 \mu \mathrm{l}$ of a suspension of competent Escherichia coli $\mathrm{INV} \alpha \mathrm{F}^{\prime}$ cells with $20 \mathrm{mM}$ $\beta$-mercaptoethanol. The cells were incubated on ice for $30 \mathrm{~min}$ and then at $42^{\circ} \mathrm{C}$ for $30 \mathrm{~s}$. They were then chilled to $4^{\circ} \mathrm{C}$ and added to $450 \mu \mathrm{l}$ of $37^{\circ} \mathrm{C} \mathrm{SOC}$ medium (28) $(2 \%$ tryptone, $0.5 \%$ yeast extract, $10 \mathrm{mM} \mathrm{NaCl}, 2.5 \mathrm{mM} \mathrm{KCl}, 10 \mathrm{mM} \mathrm{MgCl}$, $10 \mathrm{mM} \mathrm{MgSO}_{4}$, and $20 \mathrm{mM}$ glucose) and incubated for $1 \mathrm{~h}$ at $37^{\circ} \mathrm{C}$ under agitation. Twenty-five or $100 \mu \mathrm{l}$ of the cell suspension was spread onto LuriaBertani (LB) agar plates with $250 \mu \mathrm{g}$ of ampicillin $/ \mathrm{ml}$ and $50 \mu \mathrm{g}$ of X-Gal (5-bromo-4-chloro-3-indolyl- $\beta$-D-galactopyranoside) $/ \mathrm{ml}$. Plates were incubated for $16 \mathrm{~h}$; white colonies were selected as recombinants, and blue colonies were selected as controls. These were transferred either to Trypticase soy broth with $250 \mu \mathrm{g}$ of ampicillin $/ \mathrm{ml}$ or to LB broth with $250 \mu \mathrm{g}$ of ampicillin $/ \mathrm{ml}$ and incubated at $37^{\circ} \mathrm{C}$ for $16 \mathrm{~h}$ with agitation for plasmid isolation. The plasmid DNA was extracted with an alkaline lysis-polyethylene glycol (PEG) precipitation miniprep procedure (user bulletin 18; Applied Biosystems, Inc., Foster City, Calif.) for analysis by agarose gel electrophoresis as previously described. Clones that were determined to contain the proper-size insert were grown to saturation overnight in $500 \mathrm{ml}$ of LB broth with $250 \mu \mathrm{g}$ of ampicillin/ml, and the plasmid DNA was extracted either by an alkaline lysis-PEG precipitation protocol $(28)$ or with a commercial kit utilizing alkaline lysis followed by anion-exchange resin binding of plasmid DNA according to the manufacturer's directions (Maxi plasmid kit; Qiagen, Chatsworth, Calif.).

Sequencing reaction. The manufacturer's directions were followed for a cycle sequencing reaction with fluorescence-labeled nucleotides (DyeDeoxy terminator cycle sequencing kit; Applied Biosystems). Clones of the PCR+amplified partial 16S rDNA segments or whole bacterial DNA were sequenced. Briefly, 1 $\mu \mathrm{g}$ of plasmid DNA extracted by alkaline lysis followed by either PEG precipitation or anion-exchange resin binding as described in the previous section or 1 $\mu \mathrm{g}$ of bacterial DNA extracted with phenol-chloroform (28) was added to a reaction mixture containing $1 \mathrm{pmol}$ of M13 forward or reverse primers, $1100 \mathrm{R}$ reverse primers, or extension primers, $1.58 \mu \mathrm{M}$ A-DyeDeoxy, $94.74 \mu \mathrm{M} \mathrm{T}$ DyeDeoxy, $0.42 \mu \mathrm{M}$ G-DyeDeoxy, $47.37 \mu \mathrm{M}$ C-DyeDeoxy, $78.95 \mu \mathrm{M}$ dITP, $15.79 \mu \mathrm{M}$ dATP, $15.79 \mu \mathrm{M}$ dCTP, $15.79 \mu \mathrm{M}$ dTTP, $168.42 \mathrm{mM}$ Tris- $\mathrm{HCl}(\mathrm{pH}$ $9.0), 4.21 \mathrm{mM}\left(\mathrm{NH}_{4}\right)_{2} \mathrm{SO}_{4}, 42.10 \mathrm{mM} \mathrm{MgCl}$, and $4.29 \mathrm{U}$ of AmpliTaq DNA polymerase in a total volume of $20 \mu \mathrm{l}$. The reaction mixture was subjected to 25 cycles of PCR with a sequence of $96^{\circ} \mathrm{C}$ for $30 \mathrm{~s}, 50^{\circ} \mathrm{C}$ for $15 \mathrm{~s}$, and $60^{\circ} \mathrm{C}$ for $4 \mathrm{~min}$. The samples were submitted to the Microchemical Facility, Institute for Human Genetics, University of Minnesota, for automated sequencing analysis (model 573 fluorescent DNA sequencer; Applied Biosystems).

Sequence analysis. Sequences determined by the above-described methods were aligned manually with the GDE multiple sequence editor (distributed by the Ribosomal Database Project [18]) and compared with the 16S rDNA sequence for $L$. intracellularis, the swine intracellular agent of PE (GenBank accession no. U30147), with that for the intracellular agent of ferret proliferative colitis (GenBank accession no. U07570) (6), with that for another isolate of the intracellular agent of hamster PE (GenBank accession no. U07569) (6), and with another report of the sequence for this strain (auratus) of the intracellular agent of hamster PE (GenBank accession no. U06423) (26). To also determine the relationships between these organisms and their nearest taxonomic relative with pathogenic potential, $L$. intracellularis was compared with a Desulfovibrio isolate from a human liver abscess (GenBank accession no. U42221) (32) by the same methods.

Nucleotide sequence accession numbers. The sequences of the cloned $16 \mathrm{~S}$ rDNAs from each species have been submitted to GenBank with the following accession numbers: hamster, U65995; deer, U65996; ostrich, U65997.

\section{RESULTS}

Diagnosis of PE. Ilea from a hamster, an ostrich, and a deer, all with PE, were fixed, stained with hematoxylin and eosin and with Warthin-Starry silver stains, and examined by light microscopy. There was hyperplasia of the ileal crypt epithelium with silver-stained organisms present within the apical cytoplasm of crypt enterocytes in the hamster, deer, and ostrich with PE (Fig. 1).

Sequence analysis. Individual recombinant clones, each containing the partial $16 \mathrm{~S}$ rDNA sequence from the intracellular agent of PE from the hamster, the ostrich, or the deer, were selected for plasmid purification and cycle sequencing with fluorescence-labeled nucleotides and automated sequence determination. These sequences were compared with the sequence of the L. intracellularis type strain (an isolate of ileal symbiont intracellularis, NCTC 12656, grown in cell culture; GenBank accession no. U30147) (21) and with sequences determined for strains of the intracellular agent of proliferative colitis in the ferret and of the agent of PE in the hamster. A 1,109-bp sequence corresponding to bp 358 to 1465 of $L$. intracellularis was determined from the hamster sample. Sequences of 255-bp corresponding to bp 815 to 1070 of $L$. intracellularis were determined from the ostrich and deer samples. There was $100 \%$ sequence similarity between the 255 -bp sequence from $L$. intracellularis and those of the intracellular agents of PE in the hamster, deer, and ostrich (Fig. 2). There was $100 \%$ similarity over the entire 1,109 -bp sequence from the hamster and the corresponding sequence from $L$. intracellularis (data not shown). The sequences of the cloned 16S rDNAs from each species have been submitted to GenBank (see above for accession numbers). The sequences were $100 \%$ similar to the sequence of the ferret intracellular organism over this region. Our hamster sequence had $98.4 \%$ similarity over the entire 16S rDNA with another sequence (GenBank accession no. U06423) (26), of the same strain (auratus) but only $97.7 \%$ similarity with the partial sequences we determined for the deer and ostrich isolates. Another isolate of the intracellular agent of hamster PE (GenBank accession no. U07569) (6) had $98.8 \%$ 16S rDNA sequence similarity with our hamster isolate over a partial sequence that did not include the hypervariable region. $L$. intracellularis had $91 \% 16 \mathrm{~S}$ rDNA sequence 

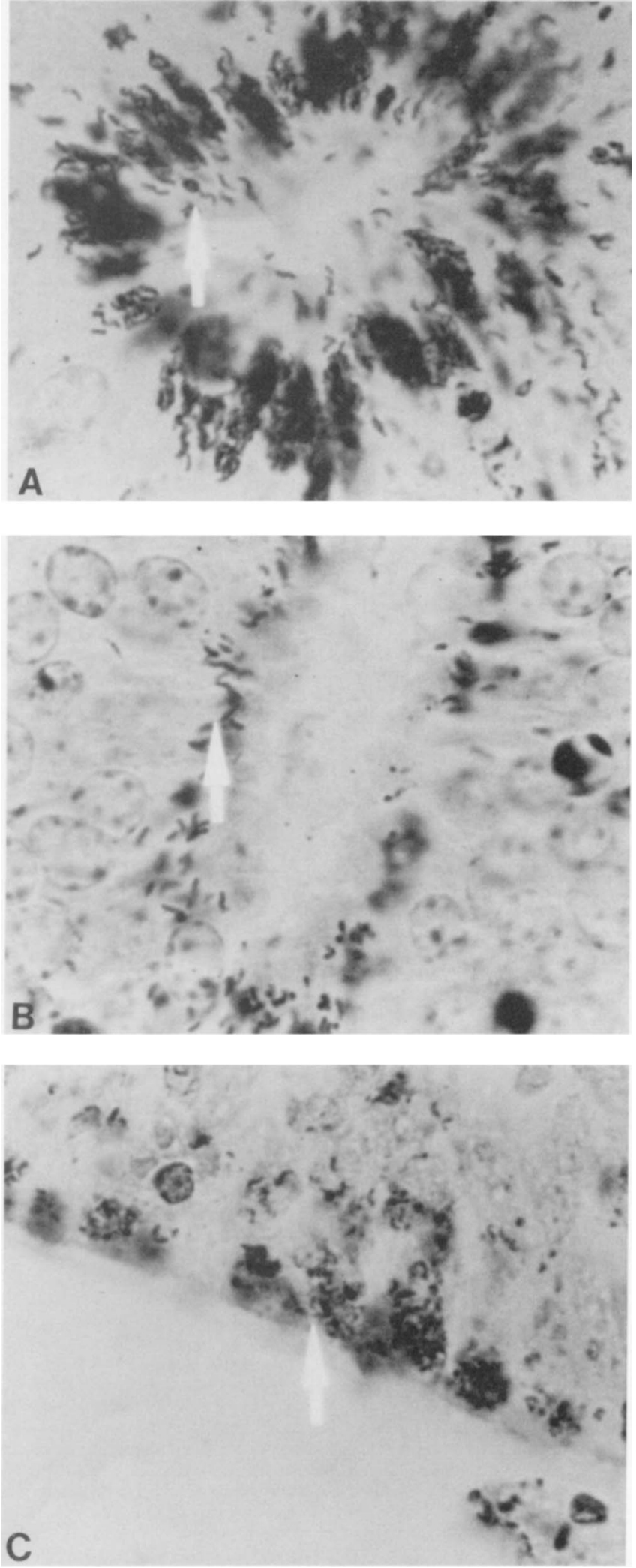

FIG. 1. Intestinal crypts from a hamster (A), a deer (B), and an ostrich (C) with PE. stained with Warthin-Starry silver stain. Numerous elongate, curved organisms are present within the apical cytoplasm of the crypt enterocytes (arrows). Magnification, $\times 660$.

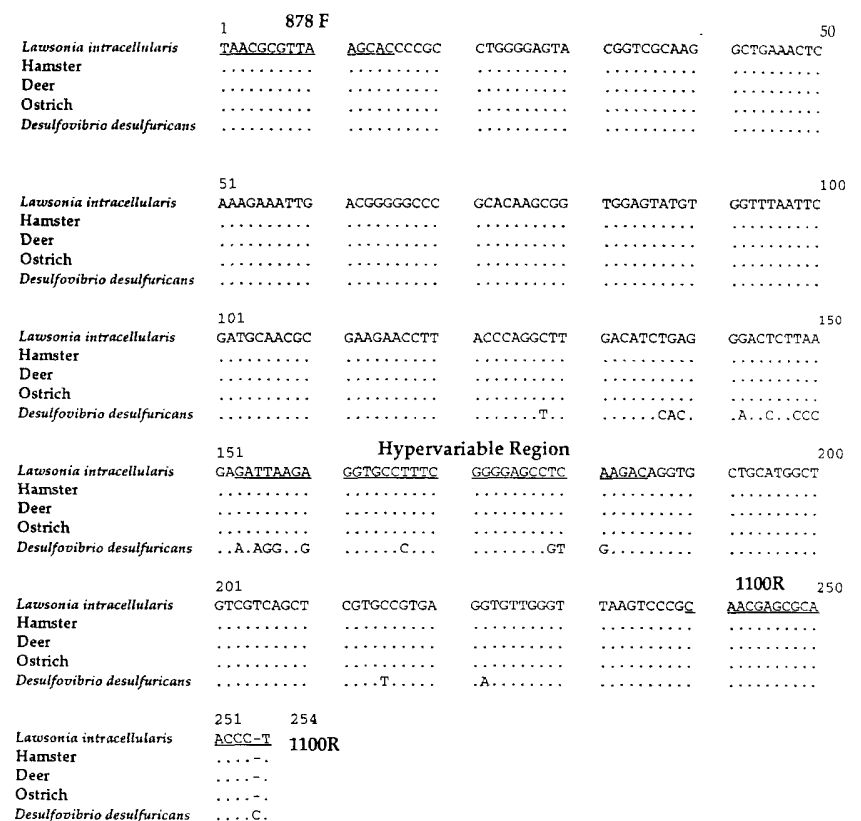

FIG. 2. DNA sequences of a portion of the $16 \mathrm{~S}$ rDNA of the intracellular agents of PE derived from the hamster (strain auratus), deer (strain 93-3669), and ostrich (strain D94-06196) compared to the consensus sequences of a pig isolate of $L$. intracellularis (NCTC $12656^{\mathbf{T}}$; GenBank accession no. U30147) and of $D$. desulfuricans (GenBank accession no. M34113), the closest relative of $L$. intracellularis. Underlined regions correspond to $878 \mathrm{~F}$, the forward primer for the PCR amplification of the intracellular organism 16S rDNA from lesions of $\mathrm{PE}$ to $1100 \mathrm{R}$, the reverse primer, and to a hypervariable region that distinguishes $L$. intracellularis from $D$. desulfuricans by nine bases. Dots indicate identical bases. Dashes indicate gaps introduced to facilitate comparisons.

similarity with a Desulfovibrio isolate from a human liver abscess.

\section{DISCUSSION}

The results of this study show that the $16 \mathrm{~S}$ rDNA sequences of the intracellular agents of PE from the pig, hamster, deer, and ostrich have high similarity, suggesting that they are all isolates of $L$. intracellularis. rDNA sequence analysis is a powerful technique that is used to identify the taxonomic position of prokaryotes (35). Partial 16S rDNA analysis has been used to determine the relationships between species of Desulfovibrio (3), the genus most closely related to $L$. intracellularis $(7,21)$. $D$. desulfuricans and $L$. intracellularis have $91 \%$ 16S rDNA sequence similarity (7). The region of the $16 \mathrm{~S}$ rDNA of the intracellular agents of PE from the hamster, deer, and ostrich that was sequenced includes a hypervariable region that differentiates $L$. intracellularis from $D$. desulfuricans, its closet relative (Fig. 2) (7). There is $96.1 \%$ similarity between $L$. intracellularis and $D$. desulfuricans across this region. There was $100 \%$ sequence similarity across this hypervariable region (and for the entire partial $16 \mathrm{~S}$ rDNA sequence we determined) between $L$. intracellularis and the intracellular agents of PE in the hamster, deer, and ostrich.

These results closely parallel those of other investigators who have shown that the intracellular agents of proliferative colitis in the ferret $(6)$ and of PE in the hamster $(6,26)$ are closely related to $L$. intracellularis, based on $16 \mathrm{~S}$ rDNA sequence similarity. We obtained a slightly different sequence for the same strain (auratus, isolated from a hamster) from that of Peace et al. (26), with only $98.4 \%$ similarity overall and $97.7 \%$ over the partial sequence we determined for the deer and 
ostrich isolates. A hamster isolate sequence obtained by Fox et al. (6) was $98.8 \%$ similar to our sequence overall; it did not include the region with the partial sequence we determined for the deer and ostrich isolates, precluding direct comparison. However, based on the fact that other isolates of the intracellular agent of PE from disparate animal species, such as the ferret, pig, deer, and ostrich, have $100 \%$ sequence similarity across the partial sequence we determined, it is likely that the differences between the hamster isolates represent sequencing errors rather than strain diversity. Different isolates of $L$. intracellularis from pigs have not shown great diversity in the $16 \mathrm{~S}$ rDNA sequences (21). Nevertheless, these similarities are high, making it likely that all of these isolates are members of the genus Lawsonia, if not the same species, $L$. intracellularis. DNA-DNA reassociation data would be needed to determine if organisms with such high $16 \mathrm{~S}$ rDNA similarities are the same species (30). However, it is not possible to perform these experiments with these organisms, because they cannot be grown on cell-free media.

The organisms in the genus Lawsonia are clearly different from $D$. desulfuricans ATCC 27774 (the type strain) (7) and from a Desulfovibrio isolate from a human liver abscess (32), based on only $91 \% 16 \mathrm{~S}$ rDNA sequence similarity. In addition to the differences in $16 \mathrm{~S}$ rDNA sequences, these organisms differ from the desulfovibrios in several important areas. They are obligate intracellular parasites $(7,15,21,31)$, whereas the desulfovibrios can be grown on cell-free media $(3,32)$. In addition, the presence of the intracellular organism is always associated with lesions, and the pathogenesis of the disease $(4-7,17,23,24,27,31)$ is clearly distinct from the diseases that have been associated with the normally nonpathogenic desulfovibrios (32).

We have previously discussed the amplification of $L$. intracellularis DNA from formalin-fixed, paraffin-embedded tissues by PCR (2). It was necessary to use prolonged digestion with proteinase $\mathrm{K}$ and subsequent extraction with diatomaceous earth in the presence of GuSCN to purify DNA for successful amplification from these samples. While the reason for this is not known, we hypothesize that either there was very little target DNA, the target DNA was extensively cross-linked by formalin fixation and inaccessible to the DNA polymerase, the bacterial cell wall was resistant to degradation, or there were PCR inhibitors present in the fixation preparation. Preparation of human or viral nucleic acids from archival tissues for PCR amplification does not require prolonged digestion $(11,29)$, while preparation of bacterial DNA may (25).

This study demonstrates that the causative agent of $\mathrm{PE}$ in pigs, L. intracellularis, is closely related or identical to the intracellular agents of PE in the hamster, deer, and ostrich. PE is emerging as a worldwide disease that occurs in many species of animals. The causative agent, $L$. intracellularis, appears to be a versatile pathogen with a wide host range. An understanding of the relationships between different isolates of this organism will greatly facilitate the study of the epidemiology of the disease.

\section{REFERENCES}

1. Boom, R., C. J. A. Sol, M. M. M. Salimans, C. L. Jansen, P. M. E. Wertheimvan Dillen, and J. van der Noordaa. 1990. Rapid and simple method for purification of nucleic acids. J. Clin. Microbiol. 28:495-503.

2. Cooper, D. M., D. L. Swanson, and C. J. Gebhart. 1997. Diagnosis of proliferative enteritis in frozen and formalin-fixed, paraffin-embedded tissues from a hamster, horse, deer and ostrich using a Lawsonia intracellularisspecific multiplex PCR assay. Vet. Microbiol. 54:47-62.

3. Devereux, R., S.-H. He, C. L. Doyle, S. Orkland, D. A. Stahl, J. LeGall, and W. B. Whitman. 1990. Diversity and origin of Desulfovibrio species: phylogenetic definition of a family. J. Bacteriol. 172:3609-3619.

4. Drolét, R., D. Larochelle, and C. J. Gebhart. 1996. Proliferative enteritis in white-tailed deer. J. Vet. Diagn. Invest. 8:250-253.

5. Duhamel, G. E., and E. B. Wheeldon. 1982. Intestinal adenomatosis in a foal Vet. Pathol. 19:447-450.

6. Fox, J. G., F. E. Dewhirst, G. J. Fraser, B. J. Paster, B. Shames, and J. C. Murphy. 1994. Intracellular Campylobacter-like organism from ferrets and hamsters with proliferative bowel disease is a Desulfovibrio sp. J. Clin. Microbiol. 32:1229-1237.

7. Gebhart, C. J., S. M. Barns, S. McOrist, G.-F. Lin, and G. H. K. Lawson 1993. Ileal symbiont intracellularis, an obligate intracellular bacterium of porcine intestines showing a relationship to Desulfovibrio species. Int. J. Syst. Bacteriol. 43:533-538.

8. Gebhart, C. J., G.-F. Lin, S. M. McOrist, G. H. K. Lawson, and M. P. Murtaugh. 1991. Cloned DNA probes specific for the intracellular Campylobacter-like organism of porcine proliferative enteritis. J. Clin. Microbiol 29:1011-1015.

9. Gebhart, C. J., S. McOrist, G. H. K. Lawson, J. E. Collins, and G. E. Ward. 1994. Specific in situ hybridization of the intracellular organism of porcine proliferative enteropathy. Vet. Pathol. 31:462--467.

10. Holyoake, P. K., R. S. Cutler, I. W. Caple, and R. P. Monckton. 1994 Enzyme-linked immunosorbent assay for measuring ileal symbiont intracellularis-specific immunoglobulin $\mathrm{G}$ response in sera of pigs. J. Clin. Microbiol. 32:1980-1985.

11. Isola, J., S. DeVries, L. Chu, S. Ghazvini, and F. Waldman. 1994. Analysis of changes in DNA sequence copy number by comparative genomic hybridization in archival paraffin-embedded tumor samples. Am. J. Pathol. 145:13011308 .

12. Jones, G. F., P. R. Davies, R. Rose, G. E. Ward, and M. P. Murtaugh. 1993 Comparison of techniques for diagnosis of proliferative enteritis of swine. Am. J. Vet. Res. 54:1980-1985.

13. Jones, G. F., G. E. Ward, M. P. Murtaugh, G. Lin, and C. J. Gebhart. 1993. Enhanced detection of intracellular organism of swine proliferative enteritis, ileal symbiont intracellularis, in feces by polymerase chain reaction. J. Clin. Microbiol. 31:2611-2615.

14. Lawson, G. H. K., and S. McOrist. 1993. The enigma of the proliferative enteropathies: a review. J. Comp. Pathol. 108:41-46.

15. Lawson, G. H. K., S. McOrist, S. Jasni, and R. A. Mackie. 1993. Intracellular bacteria of porcine proliferative enteropathy: cultivation and maintenance in vitro. J. Clin. Microbiol. 31:1136-1142.

16. Lawson, G. H. K., S. McOrist, A. C. Rowland, E. McCartney, and L. Roberts. 1988. Serological diagnosis of the porcine proliferative enteropathies: implications for aetiology and epidemiology. Vet. Rec. 122:554-557.

17. LeMarchand, T., D. Duncan, T. Tully, Jr., and M. Lopez. 1995. Intracellular Campylobacter-like organisms (CLO) associated with cloacal prolapse and enterocolitis in emus (Dromaius novaehollandiae). Vet. Pathol, 32:587. (Abstract.)

18. Maidak, B. L., N. Larsen, M. J. McCaughey, R. Overbeek, G. J. Olsen, K. Fogel, J. Blandy, and C. R. Woese. 1994. The Ribosomal Database Project Nucleic Acids Res. 22:3485-3487.

19. McCormick, B. M., D. Hasse, and R. P. Monckton. 1995. Detection of ileal symbiont intracellularis in porcine faecal samples by polymerase chain reaction. Vet. Microbiol, 47:387-393.

20. McOrist, S., R. Boid, G. H. K. Lawson, and I. McConnell. 1987. Monoclonal antibodies to intracellular campylobacter-like organisms of the porcine proliferative enteropathies. Vet. Rec. 121:421-422.

21. McOrist, S., C. J. Gebhart, R. Boid, and S. M. Barns. 1995. Characterization of Lawsonia intracellularis gen. nov., sp. nov., the obligately intracellula bacterium of porcine proliferative enteropathy. Int. J. Syst. Bacteriol. 45: $820-825$.

22. McOrist, S., C. J. Gebhart, and G. H. K. Lawson. 1994. Polymerase chain reaction for diagnosis of porcine proliferative enteropathy. Vet. Microbiol. 41:205-212.

23. McOrist, S., S. Jasni, R. A. Mackie, N. MacIntyre, N. Neef, and G. H. K. Lawson. 1993. Reproduction of porcine proliferative enteropathy with pure cultures of ileal symbiont intracellularis. Infect. Immun. 61:4286-4292.

24. McOrist, S., G. H. K. Lawson, A. C. Rowland, and N. MacIntyre. 1989. Early lesions of proliferative enteritis in pigs and hamsters. Vet. Pathol. 26:260264.

25. Nishimura, M., K. S. Kwon, K. Shibuta, Y. Yoshikawa, C. Oh, T. Suzuki, et al. 1994. An improved method for DNA diagnosis of leprosy using formaldehyde-fixed, paraffin-embedded skin biopsies. Mod. Pathol. 7:253-256.

26. Peace, T. A., K. V. Brock, and H. F. Stills, Jr. 1994. Comparative analysis of the $16 \mathrm{~S}$ rRNA gene sequence of the putative agent of proliferative ileitis of hamsters. Int. J. Syst. Bacteriol. 44:832-835.

27. Rowland, A. C., and G. H. K. Lawson. 1992. Porcine proliferative enteropathies, p. 560-569. In A. D. Leman, B. E. Straw, W. L. Mengeling, S. D'Allaire, and D. J. Taylor, (ed.), Diseases of swine, 7th ed. Iowa State University Press, Ames.

28. Sambrook, J., E. F. Fritsch, and T. Maniatis. 1989. Molecular cloning: a laboratory manual, 2nd ed. Cold Spring Harbor Laboratory Press, Cold Spring Harbor, N.Y. 
29. Sorg, I., and A. Metzler. 1995. Detection of borna disease virus RNA in formalin-fixed, paraffin-embedded brain tissues by nested PCR. J. Clin. Microbiol, 33:821-823.

30. Stackebrandt, E., and B. M. Goebel. 1994. Taxonomic note: a place for DNA-DNA reassociation and 16S rRNA sequence analysis in the present species definition in bacteriology. Int. J. Syst. Bacteriol. 44:846-849.

31. Stills, H. F., Jr. 1991. Isolation of an intracellular bacterium from hamsters (Mesocricetus auratus) with proliferative ileitis and reproduction of the disease with a pure culture. Infect. Immun. 59:3227-3236.

32. Tee, W., M. Dyall-Smith, W. Woods, and D. Eisen. 1996. Probable new species of Desulfovibrio isolated from a pyogenic liver abscess. J. Clin. Microbiol. 34:1760-1764.

33. Weisburg, W. G., S. M. Barns, D. A. Pelletier, and D. J. Lane. 1991. 16S ribosomal DNA amplification for phylogenetic study. J. Bacteriol. 173:697703.

34. Williams, N. M., L. Harrison, and C. J. Gebhart. 1996. Proliferative enteropathy in a foal caused by Lawsonia intracellularis-like bacterium. J. Vet. Diagn. Invest. 8:254-256.

35. Woese, C. R. 1987. Bacterial evolution. Microbiol. Rev. 51:221-271.

36. Woods, L. W. 1996. Personal communication. 